Jap. J. Leprosy 48, 3 (1979)

\title{
Experimental Transmission of M. leprae in Mice Treated with Anti-lymphocyte Serum
}

\author{
KIYO SUSHIDA and MARIKO WAKAI \\ (Department of Microbiology, Tokyo Women's Medical College, Tokyo)
}

\begin{abstract}
Anti-mouse (C3H/He) ALS was used severally for immunosuppressing four different strains (C3H/He, IH-F, IB-F \& ddy) of ?mice, and then leprosy bacilli taken from lepromatous patients were inoculated into their testes.

When the strain of mice was the same as in the $\operatorname{ALS}(\mathrm{C} 3 \mathrm{H} / \mathrm{He})$, they lived less than 6 months after the leprosy bacilli inoculation. Despite this, they lived for a long times on the skin graft transplantation $(3,4)$. That is, these ALS treated mice might be more wasting to these bacterial infection than the skin transplantation tests.

The positive data in the present examination were that the acidfast bacilli were found to be abundant intracellularly, as globi $(+G)$. The effects of $\mathrm{C} 3 \mathrm{H} / \mathrm{He}$-ALS were different as far as their mouse strains are concerned: The ddy mice injected with ALS and infected with leprosy bacilli had an antipodal reaction to that of $\mathrm{C} 3 \mathrm{H} / \mathrm{He}$ mice. However, both $\mathrm{C} 3 \mathrm{H} / \mathrm{He}$ and ddy mice were negative to infection $(+\mathrm{G})$ of leprosy bacilli. In the hybrid mice, IH-F mice originated from $\mathrm{C} 3 \mathrm{H} / \mathrm{He}$ were similarly reactive to ALS and leprosy infection to $\mathrm{C} 3 \mathrm{H} / \mathrm{He}$ mice, and IB-F mice orginated from $\mathrm{C} 37 \mathrm{BL} / 6$ survived for 8 months longer than the $\mathrm{C} 3 \mathrm{H} / \mathrm{He}$ groups, and many AFB-loaded cells were observed in these testes.
\end{abstract}

\section{抗リンパ球血清投与マウスへの人らい菌接種実験 \\ 須子田キヨ若井真理子 \\ (東京女子医科大学 微生物学教空)}

（受付 : 1979年 1 月19日）

抗リンパ球血清 (ALS) が移植免没を抑制することは すでに知られている。また ALS 注射して動物へら い菌を接種した実験の報告もある1,2。。かかる実験に晾 いては被検動物と同系統マウスリンパ球から得られた ALS が用いられている。異種動物からの ALS の利用 は臨床的必要性から移植免没に関する研究が多い。異種 動物のリンパ球から得られた ALS の細胞性免疫の抑制 力注同種からのものに比べてやや低下することはあって も充分利用し得ると報告されている3,4,5)。従ってマウス
由来の ALS を同種の異系統マウスに用い，人らい菌接 種実験を行らことは同系統マウスの場合とほぼ同様の結 果が得られるであるらと考え， C3H/He マウスリンパ球 由来の ALS を C3H/He マウス和よびこれと系統を異 にするマウスに注射して，人らい菌接種実験を行った。

\section{実験方法}

抗リンパ球血清 (ALS) は $\mathrm{C} 3 \mathrm{H} / \mathrm{He}$ マウスの腸間膜 リンパ節より採取したリンパ球を抗原とし，ウサギに注 
射して得られた。製作日を異にする4つの ALS が用い られた。即ち $65 ， 72 ， 73 ， 91 て ゙ ，$ 単一或いは 2 種を混 合して用いた (これらのALS 注本学心臟血圧研究所千 葉智世教授上り分与)。いすれ视の ALS も同系統マウ スに注射すると，末梢リンパ球数を約10\%減少させ， $\mathrm{C} 57 \mathrm{BL} / 6$ マウスの皮膚片を ALS 投与 $\mathrm{C} 3 \mathrm{H} / \mathrm{He}$ マウ スの背部に移植すると，移植皮䖉片の生着日数は，無処 置対照群の 3 倍以上の延長がみられる3,4)。

ALS 注射量抒よび方法は, 本実験の初期には, 上記 皮虚移植実験に做い，菌接種前に ALS $0.25 \mathrm{ml}$ 宛毎日 数日間，背部皮下に 注射した。人らい菌接種後注 同量 を，第 1 週日は隔日，第 2 週目は週 2 回，第 3 週以降洛 週 1 回宛を被検マウスの死亡するまで注射した。しかし 皮膚移植実験においては成功であったこのような ALS 投与法では，同采統の $\mathrm{C} 3 \mathrm{H} / \mathrm{He}$ マウスに抒いては，人 らい菌接種後早期に死ししたためその後の実験において は ALS 量を減少し, 1 回注射量を $0.2 \mathrm{ml}, 0.15 \mathrm{ml}$ およ び0.1ml とした。なお，途中から $0.05 \mathrm{ml}$ とした例もあ った。

被検マウス注同系統 C3H/He マウスの他, ddy, IB-F， および IH-F の 4 采統を用いた。IB-F は (ICR 果 C57BL/6 今)の混血で，(兄妹交配で維持している)野生 色マウスで約 8 代交配のものである。IH-F は（ICR 우 $\times \mathrm{C} 3 \mathrm{H} / \mathrm{He}$ 令)の混血で同じく野生色のマウスである。い ずれも当教室にて試作した雑種で，生後1.5力月以上の 成熟オスマウスを用いた。各組ともALS 注射群と, 非 注射の対照群とに分汀た。
ら以菌接種，使用菌は LL 38，LL 39，LL 46，LL 48, LL 49, LL 50, おょよひ LL 55の 7 株で，いずれも らい腫攋患者から採取されたむのである。結節は乳鉢に て拁り，生食水にて乳剂とし，粗大組織片を除去した 後，接種菌数が $10^{4}$ 個の抗酸菌となるように希釈したも のを左右の精栄に分けて接種した。また別に一部皮下に 接種したものもあった。早期に死亡したものについては らい菌接種成績加ら除外し，6力月以上生存したマウス における成績を採用した。抗酸菌の検出法法彷来行って きた方法と同様に，菌接種部の精紧断面のスタンプ標本 について, 判定の基準としては細胞内に増殖とみられる 抗酸菌（globi）のあるものを陽性とした。皮下接種した ものでは同様に皮下組織の伸展標本について実験した。 陽性の一部のものについては組織標本によって主として 菌の増殖部位について検討した。

\section{実 験 成績}

ALS を注射し，らい菌を接種したマウスの生存日数 を表 1 に示した。ALS と同系統 $\mathrm{C} 3 \mathrm{H} / \mathrm{He}$ マウスに㧍け る生存日数は暴系統マウスのそれに比べて早期に死亡す るものが多く，同系統，異系統間に差のあることがみと められた。

即ち実験 1 から5に㧍いて用いられた $\mathrm{C} 3 \mathrm{H} / \mathrm{He}$ マウ スでは 6 力月以上生存するものがなく，本実験成績を 得る目的を達寸ることはできなかったが，用いられた ALS はそれぞれ などがあり，また接種されたらい結節もそれぞれ LL

Table 1 Survival Times of various Strains of ALS-treated Mice inoculated with M. Leprae

\begin{tabular}{|c|c|c|c|c|c|}
\hline \multirow{2}{*}{$\begin{array}{l}\text { Mouse } \\
\text { strain }\end{array}$} & \multirow{2}{*}{$\begin{array}{l}\text { No. of } \\
\text { examin. }\end{array}$} & \multirow{2}{*}{$\begin{array}{l}\text { Survival } \\
\text { day* }\end{array}$} & \multicolumn{2}{|c|}{ ALS $\left(\mathrm{C}_{3} \mathrm{H} / \mathrm{He}\right)$} & \multirow{2}{*}{$\begin{array}{l}\text { M. Leprae } \\
(\mathrm{LL})\end{array}$} \\
\hline & & & Dose/day & Batch & \\
\hline \multirow{5}{*}{$\mathrm{C} 3 \mathrm{H} / \mathrm{He}$} & 1 & 19 & $0.2 \mathrm{ml}$ & $\# 65$ & 48 \\
\hline & 2 & 89 & 0.25 & 73 & 39 \\
\hline & 3 & 165 & 0.25 & 91 & 46 \\
\hline & 4 & 151 & 0.15 & $65+73$ & 50 \\
\hline & 5 & 168 & 0.1 & $65+73$ & 49 \\
\hline $\mathrm{IH}-\mathrm{F}$ & 7 & $(60) 240<$ & $(0.1) 0.05$ & 73 & 55 \\
\hline IB-F & 5 & 235 & 0.1 & $65+73$ & 49 \\
\hline \multirow{2}{*}{ ddy } & 2 & $255<$ & 0.25 & 73 & 39 \\
\hline & 6 & $265<$ & 0.25 & $65+72$ & 38 \\
\hline
\end{tabular}

*... The last survival day of the ALS-treated mouse inoculated with M. Leprae. 


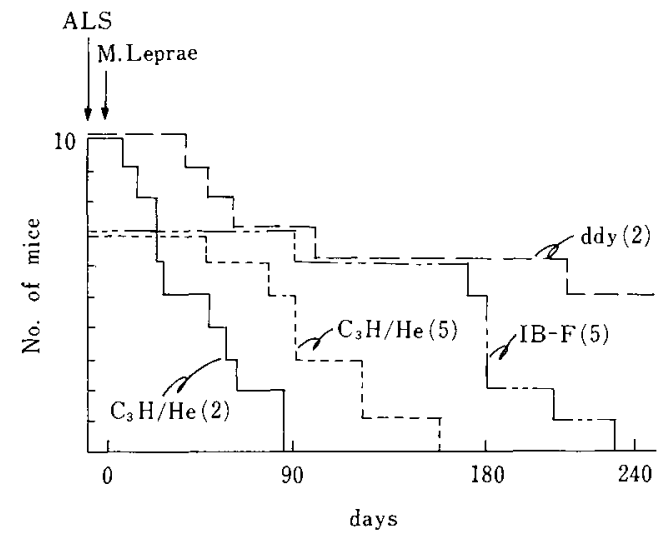

Fig. Comparison of the survival days in the mice, ALS-treated and injected with M. leprae : - . - C C $3 \mathrm{H} / \mathrm{He} \&$ - . ddy mice injected ALS $(\$ 73,0.25 \mathrm{ml})$ and LL 39 of leprous bacilli on the exp. $2 ; \cdots \mathrm{C} 3 \mathrm{H} / \mathrm{He} \& \cdots-\mathrm{IB}-\mathrm{F}$ mice injected ALS ( $\$ 65+73,0.1 \mathrm{ml})$ and LL 49 on the exp. 5.

39，46，48，49掠よび50であって，生存日数の長短を比 較することはできなかった。しかし No. 2 と No. 5 で は同じALS と同じ菌株をそれぞれ同量注射したので， この際の $\mathrm{C} 3 \mathrm{H} / \mathrm{He}$ マウスと他の系統マウスとの生存日 数の差異を図に示した。

図に示すよらに実験 2 では ddy と $\mathrm{C} 3 \mathrm{H} / \mathrm{He}$ マウスに \#730 ALS 0.25ml 宛注射し，同一菌株 (LL 39) が 同量ずつ接種された。両者の生存日数を比ベると, ALS と同系統の $\mathrm{C} 3 \mathrm{H} / \mathrm{He}$ マウスでは最も長期に生存したも のは89日であったが，ddy は長期にわたり生存し255日 目に屠殺した。実験 5 では（\$65+73）ALSを0.1ml 宛注射し，LL 49株が接種された。 $\mathrm{C} 3 \mathrm{H} / \mathrm{He}$ マウスでは
1 匹のみが168日まで生存し，IB-F マウスでは235日ま で生存した。

らい菌接種成績汢，LL 38，LL 39株を接種した ddy 系マウスと, IB-F マウスの LI 49怢を接種したものに お沙る成績を表 2 に示した。これらのマウスはいずれも 異系統マウスのものである。 LL 38株接種の ddy マウ スでは ALS 注射群では11匹中 6 匹が265日目屠殺する まで生存した。接種部の皮下組織伸展標本中に抗酸菌の みとめられたのは ALS 群で 6 匹中 1 匹に少数の抗酸菌 をみとめた。対照群で法同じく皮下組織伸展標本中の細 胞内に抗酸菌をみとめるものが11匹中 1 匹あった。

なお LL 38株は再燃未治療患者から採取された結節 で，菌は染色性の良好な杆状の抗酸菌を多数検出された ものである。同じく ddy マウスで LL 39株接種実験で はALS 群では10匹中 5 匹，対照群では10匹中 8 匹が生 存し，255日で屠殺し抗酸菌の検出を行ったがいずれる 陰性であった。この LL 39株の結節は 3 年前かららい が発症していたが治療を行っていない，末治療患者加ら のものである。

LL 49株接種実験では ALS 量を0.1ml としたためか $\mathrm{C} 3 \mathrm{H} / \mathrm{He}$ マウスでむ5.5力月まで生存した。死亡マウス については寸べて検查を行ったが抗酸菌は検出しなかっ た。IB-Fマウスでは 6 力月後に 3 匹が死亡し、そのうち 1 匹に globi を含む抗酸菌を証明したが，これら globi は末だ少数であった。7力月後と，8力月後にそれぞれ 1 匹ずつが死亡した。いずれも接種部に globi をみと めた。組織標本によって，精巣被膜下および間質に抗酸 菌をみとめた。 8 力月後に死亡したマウスでは写真に示 ように抗酸菌の増殖により間質は增大し，精宩実質の圧 迫崩壊を示す部分もみとめられた。 8 力にに屠殺した 5 匹の対照マウスはいずれも陰性であった。LI 49株は以

Table 2 Experimental Transmission in ALS-treated Mice with M. Leprae

\begin{tabular}{|c|c|c|c|c|c|}
\hline \multirow{2}{*}{$\begin{array}{l}\text { Mouse } \\
\text { srtain }\end{array}$} & \multirow{2}{*}{$\begin{array}{l}\text { No. of } \\
\text { examin. }\end{array}$} & \multirow{2}{*}{$\begin{array}{l}\text { M. Leprae } \\
\text { (LL) }\end{array}$} & \multirow{2}{*}{$\begin{array}{l}\text { Survival } \\
\text { months }\end{array}$} & \multicolumn{2}{|c|}{$\operatorname{AFB}(+\mathrm{G})$ in Testes of Mice } \\
\hline & & & & ALS-treat. & Non-treatment \\
\hline \multirow{3}{*}{ IB-F } & \multirow{3}{*}{5} & \multirow{3}{*}{49} & 6 died & $1 / 3$ & \\
\hline & & & $7 \prime \prime$ & $1 / 1$ & \\
\hline & & & $8 \prime \prime \prime$ & $1 / 1$ & $0 / 5$ (killed) \\
\hline \multirow{2}{*}{ ddy } & 6 & 38 & 9 killed & $* 1 / 6$ & $*_{1 / 11}^{\prime \prime}$ \\
\hline & 2 & 39 & $8.5 \prime \prime$ & $0 / 5$ & $0 / 8 \quad \prime \prime$ \\
\hline $\mathrm{IH}-\mathrm{F}$ & 7 & 55 & $8 \quad \prime \prime$ & $0 / 2$ & $0 / 4 \quad \prime \prime$ \\
\hline
\end{tabular}

* AFB $(+G)$ were found in subcutaneous tissue of mice by spread tissue preparations. 
前に治療したことはあるが結節採取前 6 力月間は無治療 といら患者からのものであった。

LL 55株接種の IH-F マウスは 5 匹中 3 匹が，2 カ月 で死亡したので ALS 量を $0.1 \mathrm{ml}$ から0.05ml 宛に減量 したところ，8 力月目屠殺するまで生存し得た。しかし 抗酸菌をみとめることはできなかった。また対照の 4 匹 中 1 匹は11力月で死亡，12力月まで生存したものを屠殺 したがいずれも陰性であった。LL 55株は再然末治療患 者由来の菌であるが，接種に用いた抗酸菌の染色状態は
悪く，浪とんど顆粒状のものが大半をしめていた。

\section{考察}

細胞性免疫抑制の日的で抗リンパ球血清を用いること は基礎研究の目的のみならず，臨床上移植免疫の抑制法 としてすでに忘用されている。らい菌は細胞内感染増殖 （globi）を特徵とするので，ALSをマウスに注射して らい菌接種を行った。用いた ALS は $\mathrm{C} 3 \mathrm{H} / \mathrm{He}$ マウス リンパ球由来のものでめったが，同系統マウスを用いた

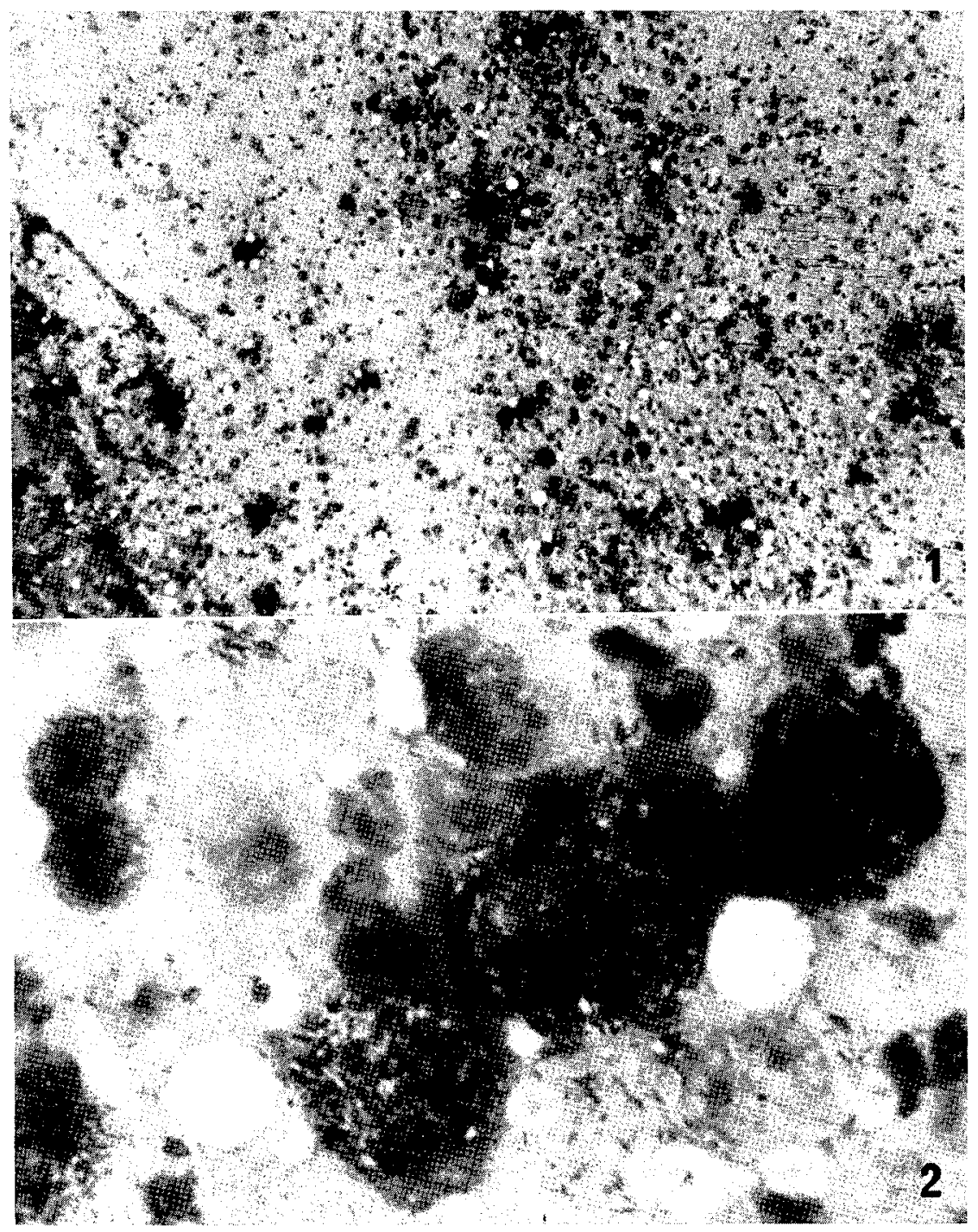

Fig. $1 \& 2$ Acid-fast bacilli (globi) in the stamp-smear sample of test is of ALS-treated IB-F mouse 8 months after inoculation with LL 49 leprous bacilli; $1-100 x$ \& 2-1000x magnification. Ziehl-Neelsen stain. 


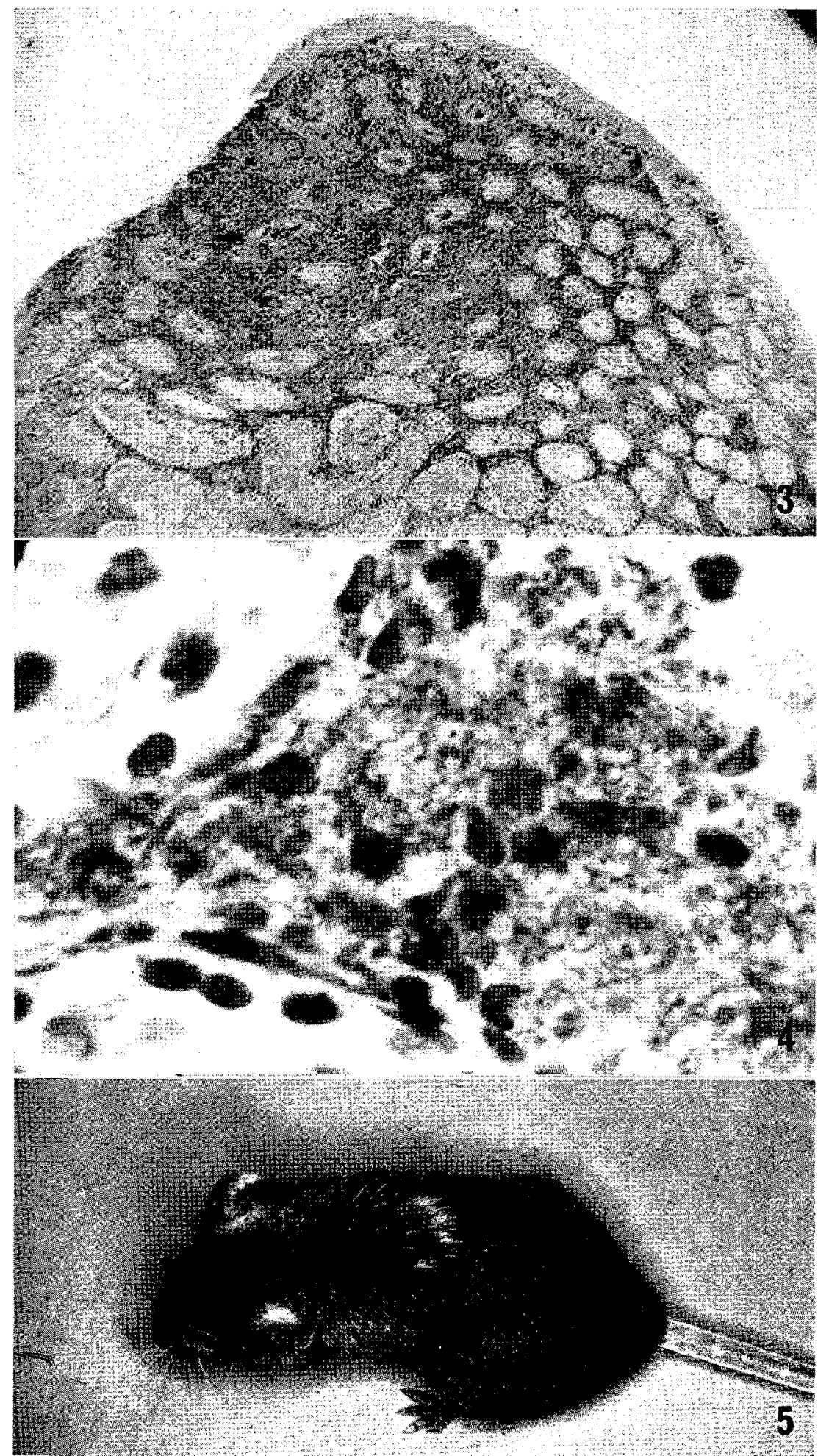

Fir. 3 \& 4 Lesion in the testis of above mouse; $3-35 x \& 4-1000 x$ magnification.

Fig. 5 Skin transplantation on the IB-F mouse, survived over 90 clays. 
実験では前述の如く6力月以上の生命を維持することが できず，らい菌接種実験における結果は得られなかっ た。参考として 6 力月以内に死亡したマウスについても す心て抗酸菌の検索を行ったが, 散在性の少数の菌をみ とめることはあっても增殖像とは考えられず従ってすべ て陰性とした。ALSを注射し，皮膚移植をぼこした もの ${ }^{6)}$, および ALS 非注射でらい菌のみ接種した $\mathrm{C} 3 \mathrm{H} / \mathrm{He}$ マウス (LL 39株接種で汉 9 力月で, LL 50株 では 8 力月で屠殺した。LL 46，48，49株では ALS 注 射群死滅後㞜殺した）では長期に生存し得たので，らい 菌接種の場合に6力月以前に死滅した理由は明らかでは ないが，強い免疫抑制をらけているので，少くとも邓ー ドマウスに準じた無菌飼育を行らならば長期の観察が可 能となりよい成績が得られるかも知れない。

これに比べて異采統マウスでは，同系統マウスに比べ て恐らくは免疫抑制作用がそれ程強くなく，従って上記 接種材料による毒作用も弱く，ほどほどに抵抗性を低下 できた IB-F の如きマウスではらい囷の増殖に必要な 程度の期間長命を得, 陽性成績を得たものと考える。し かし dd 系ではこれより更に延命し得たが，このことは 有効な免疫抑制作用が得らなかったと考えられ，実験結 果もす心゙て陰性であった。IH-F マウスは ALS 0.1ml 宛注射して実験を初めたが早期に死亡し，その傾向は同 系統の $\mathrm{C} 3 \mathrm{H} / \mathrm{He}$ マウスのそれに類似の様相を示した。 この $\mathrm{IH}-\mathrm{F}$ は $\mathrm{C} 3 \mathrm{H} / \mathrm{He}$ をオスとして交配して得られた もので色も野生色であったので同様の因子を持っている のではないかと推定された。それ故，実験の途中からで はあったが，ALS 量を $0.05 \mathrm{ml}$ 究として減量したとこ ろ，その後死亡するものなく，240日で屠殺するまで生 存した。しかしこの量では免疫抑制をらるのには充分で ないと思われ，その実娩成績もすべて陰性であった。

異系統マウスのうち globiをみとめたのは IB-F の みであった。新たに兄妹交配を行い IB-F 3 代目のマウ スを得て，これに $\mathrm{C} 3 \mathrm{H} / \mathrm{He}$ マウスの皮膚移植を行っ たところ，移植皮膚片の生着日数は90日以上に及んだ (Fig. 5)。

患者材料からのらい菌をマウスに接種する場合には， 菌の側のマウスに対する感染力に差のあることを著者ら は発表したが7，ALSを用いる場合にはマウスの系統 によって免疫抑制の程度に差があって，免疫抑制力の強 いと思われた同系統 $\mathrm{C} 3 \mathrm{H} / \mathrm{He}$ マウスでは長期に生存し 得す，逆に生存し得た dd 系マウスではほとんどその影 響がみられないといら結果であった。IB-F はその中間
で，好結果を得たものと考える。しかし適当な ALS と 被検マウス，そして感染力のあるらい菌とい53つの組 合せを容易に得るということは困難なことかも知れな い。しかしそのらちいずれかを一定にすることができれ ば実験目的によっては有効な方法と考える。

ALS 注射によるらい菌感染のマウスの組織における 増殖像は, 従来著者らの行って来たらい菌に対するマウ 又の抵抗性を抑制方方方法，即ち131I 注射 ${ }^{8,9)}$ ，放射線 照射10処置等の感染陽性マウスのそれは，ALS の場合 とほぼ同様であって，抗酸菌は接種部の精巣被膜おうざ 被膜下，更に閒質へと抬がり，菌増殖による間質の拡大 に伴い，精細胞の压迫崩壤がみとめられた。胸腺欠損の ヌードマウスの如く, 精菓接種により全身感染をみとめ るもの11はなかったが，リンパ節，脾臓，精夈部の脂肪 体中に抗酸菌を筫喰した単細胞を多数みとめるものはあ った。

\section{結論}

抗リンパ球血清 (ALS) をこれと同系統 $(\mathrm{C} 3 \mathrm{H} / \mathrm{He})$ マウスおよび異系統マウス（IB-F， ddy，IH-F）に注射 し，らい菌接種を行い，6力月以上生存したものについ てらい菌感染の有無を, 主として細胞内堌殖 (globi) を基準として判定した。

その結果， $\mathrm{C} 3 \mathrm{H} / \mathrm{He}$ マウスでは皮䖉移植実験に使用可 能であった ALS 注射量 $(0.25 \mathrm{ml})$ および減量 $(0.1$ $\mathrm{ml})$ ，いずれの場合も 6 力月以上生存できず，従って実 験結果は得られなかった。

ddy マウスでは0.25ml 注射量でも 9 力月以上生存す るものがあったが，反面免疫抑制が示されず，らい菌の 感染注陰性であった。 $\mathrm{IH}-\mathrm{F}$ マウスは $\mathrm{C} 3 \mathrm{H} / \mathrm{He}$ をオス 親とするせいか， $\mathrm{C} 3 \mathrm{H} / \mathrm{He}$ と同様の傾向を示し，陽性成 績は得られなかった。IB-F マウスは菌接種後 8 力月に 死亡したマウスの接種部精栄に多数の抗酸菌 (globi) 老証明した。

本研究䧆の一部は昭和52年度日米医学研究協力, らい 部門研究費によった。本研究要旨注昭和52年 5 月 18 日， 第50回日本らい学会総会（仙台市）にて発表した。らい 菌結節を分与下さいました国立全生園の各位に感謝致し ます。

\section{文献}

1) Gaugas J. M. : Enhancing effect of antilymphocytic serum on mycobacterial infections, Nature, 219 : 408, 1968. 
2) Fieldsteel A. H. and S. Gartner: Effect of thymectomy and antilymphocyte serum on mycobacterium leprae infection in mice, Infect. Immun., $12: 733,1975$.

3）千葉智世，泉二登志子：移植免疫抑制剤として の抗リンパ球血清，東京女子医大誌，41：405， 1971.

4）泉二登志子：抗リンパ球血清作製における異種 リンパ球利用の可能性について，東京女子医大 誌, $45: 948,1975$.

5) Winn J. Henry and G. Daddi: Properties of antimouse lymphocyte sera produced in various species, Federation Proceeding, 29 : $104,1970$.

6) 福士勝成, 森山昌樹, 林 芳孝, 須子田キヨ： ALS 処置マウスーの人濑菌接種実験 (2), 日本 ら以学会誌, $46: 202,1977$.
7) Sushida K. and H. Nakano: Infectiousness of human leprous bacilli in mice, XI Congreso International De La Lepra, Ciuded de México, 13-18 de Nov., 1978.

8）須子田キヨ, 平野憲正：放射性ヨウ化ナトリウ ム (131I) 注射マウス精巣に㧍ける人らい菌接種 訊験, レプラ, $40: 183,1971$.

9）須子田キヨ：妊媉中に131Iを注射したマウスか ら生れた仔マウスーの人らい菌移植実験, レプ ラ, $43: 234,1974$.

10）須子田キヨ，種村㓐子：娃娠中比放射線 $\left({ }^{60} \mathrm{CO}\right)$ を照射して生れた仔マウスのらい菌接種実験, 日本らい学会誌，48:120, 1979.

11）中野壽夫, 須子田キョ：ヌードマウスーの人ら 菌接種実験, 第51回日本ら以学会総会(沖緝), 6 月 24 日, 1977. 